\title{
Anna ChCiaŁowska
}

Uniwersytet Kardynała Stefana Wyszyńskiego

\section{ADOPCJA ZE WSKAZANIEM ZGODNIE Z NOWYM UREGULOWANIEM PRAWNYM}

\section{WPROWADZENIE}

Rodzina jest najważniejszą oraz najstarszą grupą społeczną, która służy zaspokajaniu różnorodnych ludzkich potrzeb. Jest ona elementarną i niezastąpioną częścią wspierającą rozwój każdego człowieka, a zgodnie z większością teorii socjologicznych, składa się z małżonków oraz ich naturalnych i adoptowanych dzieci. Adopcja jest to powstały z woli osób zainteresowanych stosunek prawny, który istnieje między rodzicami a ich dziećmi ${ }^{1}$. Pokrewieństwo, które jest stosunkiem prawnorodzinnym, znajduje swoje odzwierciedlenie w relacjach genetycznych. Wskazane zależności prawnorodzinne wynikają z naturalnego porządku, jednak mogą być one imitowane i temu właśnie służy instytucja przysposobienia. Zasada dobra dziecka postuluje nie tylko predyspozycje do życia w stosunku przysposobienia, ale także dotyczy jej wykonywania i ewentualnego rozwiązania. Adopcja ma na celu zaspokojenie instynktu opiekuńczego, ponieważ jej głównym przeznaczeniem jest stworzenie dziecku zastępczego środowiska rodzinnego ${ }^{2}$.

1 J. Ignatowicz, Ochrona praw rodzinnych, [w:] Kodeks rodzinny i opiekuńczy z komentarzem, red. J. Pietrzy kowski, Warszawa 1990, s. 472

2 K. Bagan-Kurluta, Przysposobienie międzynarodowe dzieci, Białystok 2009, s. 86. 
Celem artykułu jest wyjaśnienie instytucji adopcji ze wskazaniem, jej procedury, a także wyznaczenie osób uprzywilejowanych do przysposobienia. Jak wynika z nowych przepisów, zarekomendowani przysposabiający będą mieli ułatwioną procedurę adopcyjną, natomiast pozostali zainteresowani będą mogli adoptować małoletnie dziecko tylko za pośrednictwem ośrodka adopcyjnego.

Zgodnie z obowiązującymi normami prawnymi należy stwierdzić, że o charakterze przysposobienia decyduje wiele różnych okoliczności. Przysposobienie, na które została wyrażona zgoda blankietowa, staje się ex lege przysposobieniem całkowitym i wówczas strony nie mogą starać się, aby został mu nadany inny charakter. Jeśli rodzice biologiczni nie wyrazili zgody na adopcję własnego dziecka poprzez wskazanie osoby przysposabiającego, do której w obecnym stanie prawnym zalicza się krewnych i małżonka jednego z rodziców, to tego rodzaju adopcja jest przysposobieniem pełnym, chyba że sąd rodzinny orzeknie przysposobienie niepełne na podstawie art. 124 k.r.o., a wtedy jego skutkiem będzie tylko i wyłącznie powstanie stosunku pomiędzy dzieckiem a osobą adoptującą. Każdy rodzaj adopcji różni się od siebie zakresem skutków, jakie wywołuje orzeczenie jej przez sąd rodzinny. Skutki te zostały wskazane przez prawodawcę w kodeksie rodzinnym i opiekuńczym.

\section{Adopcja Ze WSKaZANiem - POJĘCiE}

Na wstępie należy zaznaczyć, że 18 września 2015 r., po upływie 30 dni od momentu ogłoszenia, w życie weszły zmiany, które zostały przewidziane ustawą z 24 lipca 2015 r. o zmianie ustawy - Kodeks rodzinny i opiekuńczy, ustawy - Kodeks postępowania cywilnego, a także ustawy o wspieraniu rodziny i systemie pieczy zastępczej (Dz. U. poz. 1199) ${ }^{3}$.

Zgodnie z sejmowym drukiem nr 2361 powyżej wspomniane zmiany miały na celu między innymi wprowadzenie do obrotu prawnego

3 K. Tryniszewska, Prawo rodzinne. Komentarz. Odpowiedzi na pytania. Wzory dokumentów. Akty prawne, Warszawa 2016, s. 97. 
legalnej definicji adopcji ze wskazaniem oraz ograniczenie tzw. podziemia adopcyjnego, które stanowi rzeczywiste zagrożenie dla dobra dziecka przysposabianego.

Jak już wcześniej wspomniano, przez przysposobienie rozumie się prawne zawiązanie sztucznych więzów rodzinnych, które pełnią funkcję wynikającą z naturalnych więzi krwi oraz pochodzenia. Innymi słowy, adopcja oznacza uznanie dziecka obcego za własne ${ }^{4}$.Adopcja ze wskazaniem to przeciwieństwo adopcji blankietowej, gdzie rodzice biologiczni dziecka wyrażają zgodę na adopcję w sposób anonimowy. Trzeba również dodać, że przysposobienie poprzez wskazanie oznacza sytuację, w której naturalni rodzice samodzielnie wskazują tych (po nowelizacji skonkretyzowanym osobom fizycznym), którym chcą oddać biologiczne dziecko 5 . Z kolei zgoda blankietowa stanowi wykonanie indywidualnych praw biologicznych rodziców, które powstają ze względu na pokrewieństwo z dzieckiem, bowiem zgoda blankietowa artykułuje możliwość wyzbycia się praw i obowiązków wynikających $\mathrm{z}$ adopcji ${ }^{6}$.

Nowelizacja kodeksu rodzinnego i opiekuńczego w art. $19^{1}$ a zakłada wskazanie osoby przysposabiającej tylko spośród konkretnego kręgu osób, tj. krewnych lub powinowatych, albo małżonka jednego z rodziców: „Rodzice mogą przed sądem opiekuńczym wskazać osobę przysposabiającego, którą może być wyłącznie krewny rodziców dziecka za zgodą tej osoby złożoną przed tym sądem. Osobą wskazaną może być również małżonek jednego z rodziców". Jest to adopcja wewnątrzrodzinna. Przysposobienie ze wskazaniem zapewnia rodziców naturalnych, że ich dziecko trafi do wskazanej osoby, którą znają. Należy również dodać, że do tego rodzaju adopcji jest potrzebna zgoda rodziców przysposabianego, gdyż jeśli nie nastąpiłoby wskazanie spokrewnionego albo powinowatego, to nie byłaby to adopcja ze wskazaniem?

4 H. HaAк, Kodeks rodzinny i opiekuńczy. Przysposobienie. Komentarz, Toruń 1996, s. 5.

5 K. Tryniszewska, op. cit., s. 96-97.

6 E. PŁonka, Przysposobienie całkowite w prawie polskim, Wrocław 1986, s. 68.

7 Ibidem, s. 97-98. 
Do momentu wejścia w życie nowelizacji kodeksu rodzinnego i opiekuńczego termin „adopcja ze wskazaniem” rozumiany był jako możliwość przysługująca rodzicom naturalnym na wskazanie osoby przysposabiającej, czyli rodziców adopcyjnych. Z kolei zgodnie z nowymi założeniami zawartymi w art. $119^{1}$ a k.r.o. wskazanie to zostało ograniczone i może nastąpić tylko spośród konkretnego kręgu osób ${ }^{8}$.

Ze względu na spokrewnienie lub spowinowacenie $\mathrm{z}$ rodzicami naturalnymi dziecka stosuje się uproszczoną procedurę adopcyjną. Wskazani kandydaci na adoptujących przez rodziców biologicznych nie muszą posiadać szkolenia kwalifikacyjnego organizowanego przez ośrodek adopcyjny ${ }^{9}$.

Zmiana przepisów dotyczących adopcji ze wskazaniem miała przede wszystkim na celu:

- ograniczenie tzw. podziemia adopcyjnego, które zagraża prawom i dobru dzieci, a także:

- wprowadzić taką terminologię ustawową adopcji ze wskazaniem, której treść:

- pozwoli na zachowanie przysposobienia pełnego jako podstawowej formy adopcji,

- przekona, że dziecko pochodzące z danej rodziny winno w niej pozostać,

- uchroni dzieci przed celami finansowymi, czyli nie pozwoli na przekazywanie dzieci przez rodziców biologicznych do osób przysposabiających za odpowiednią opłatą finansową,

- uchroni dzieci przed ich wychowywaniem przez osoby nieposiadające odpowiednich kwalifikacji, predyspozycji osobistych czy moralnych do opieki nad dziećmi ${ }^{10}$.

$8 \quad$ Ibidem.

9 Ibidem.

10 Pismo Komisji Polityki Społecznej i Rodziny z 14 marca 2014 r., druk sejmowy nr 2361, Projekt ustawy o zmianie Kodeksu rodzinnego i opiekuńczego oraz Kodeksu postępowania cywilnego. Uzasadnienia, s. 4-5, http://www.sejm.gov.pl/sejm7.nsf/ PrzebiegProc.xsp?nr=2361, dostęp 5 grudnia 2017 r. 


\section{PraCe NAD NOWElizaCją I NOWA REgulaCjA AdOPCJi ZE WSKAZANIEM}

Dnia 1 stycznia 2012 r. weszła w życie ustawa o wspieraniu rodziny i systemie pieczy zastępczej, która zawierała dział dotyczący postępowania adopcyjnego. Na mocy wspomnianej ustawy dodano do wymagań, które winni spełniać przysposabiający, obowiązek posiadania opinii kwalifikacyjnej oraz świadectwo ukończenia szkolenia organizowanego przez ośrodek adopcyjny ${ }^{11}$.

Również od 2012 r. Rzecznik Praw Dziecka występował między innymi do Przewodniczącego Sejmowej Komisji Polityki Społecznej i Rodziny o podjęcie działań, które miały doprowadzić do nowelizacji kodeksu rodzinnego i opiekuńczego przez ograniczenie tzw. adopcji ze wskazaniem ${ }^{12}$.

Pierwszy raz 24 października 2012 r. Rzecznik Praw Dziecka wystąpił z taką prośbą do Ministra Pracy i Polityki Społecznej o podjęcie działań, które winny zmierzać do zmiany norm dotyczących omawianego zagadnienia. W piśmie kierującym Rzecznik zaproponował nową regulację przepisu art. $119^{1}$ k.r.o. poprzez dodanie do tegoż artykułu $\$ 4$ o następującej treści: „Jeżeli jest to zgodne z dobrem dziecka, przysposobienie może nastąpić na wniosek osoby wskazanej przez matkę lub ojca, którą może być wyłącznie krewny lub powinowaty dziecka”.

Trzeba również nadmienić, że powyższa reakcja Rzecznika była spowodowana tym, że do Biura Rzecznika Praw Dziecka zaczęły napływać liczne sygnały dotyczące podziemia adopcyjnego, które zaczęło się rozprzestrzeniać na forach internetowych. W związku z tym 19 kwietnia 2013 r. Rzecznik Praw Dziecka wystąpił ponownie, między innymi do Ministra Pracy i Polityki Społecznej, z kolejnym już wnioskiem o dokonanie zmian w normach dotyczących przysposobienia ze wskazaniem,

11 E. Holewińska-Łapińska, Przysposobienie rozwiązywalne w orzecznictwie sądów powszechnych, Instytut Wymiaru Sprawiedliwości, Warszawa 2014, s. 1-3, https:// www.iws.org.pl/pliki/files/_Przysposobienie\%20rozwi\%C4\%85zywalne\%20w\%20 orzecznictwie\%20s\%C4\%85d\%C3\%B3w\%20powszechnych\%20wersja\%20bez\%20 sygnatur.pdf, dostęp 5 grudnia 2017 r.

12 Ibidem. 
a 23 lipca 2013 r. nastąpił odzew Ministra Pracy i Polityki Społecznej. W swojej odpowiedzi Minister potwierdził, że proponowane rozwiązanie przez Rzecznika (ograniczające krąg osób, którym rodzice naturalni małoletniego dziecka mogą przekazać władzę rodzicielską krewnym i powinowatym) zasługuje na aprobatę ze względu na to, że zaproponowany projekt $\mathrm{w}$ dużej mierze ograniczałby zjawisko pozyskiwania korzyści majątkowych z tytułu wskazania osób adoptujących. Jednocześnie dodał także, że zawężenie kręgu osób jedynie do spokrewnionych i spowinowaconych budzi liczne wątpliwości merytoryczne. Minister Pracy i Polityki Społecznej z uwagi na swoje sceptyczne nastawienie uwzględnił przede wszystkim możliwość pojawienia się takiej sytuacji, w której rodzice naturalni nie chcą albo nie mają możliwości, aby wskazać spokrewnionych lub powinowatych. Dodał także, że: „Wolą rodziców biologicznych może być przysposobienie ich dziecka przez osobę niespokrewnioną, czy niespowinowaconą, ale będącą w bardzo bliskiej zażyłości zarówno z rodzicami biologicznymi, jak i samym dzieckiem, którą darzą większym zaufaniem niż osoby z rodziny"13.

Konkludując, członkowie Komisji Polityki Społecznej i Rodziny uznali argumenty Rzecznika Praw Dziecka za przekonujące i 14 marca 2014 r. wnieśli do Sejmu projekt ustawy o zmianie Kodeksu rodzinnego i opiekuńczego oraz niektórych norm Kodeksu postępowania cywilnego ${ }^{14}$.

Jednakże 8 maja 2014 r. Krajowa Rada Sądownictwa negatywnie wypowiedziała się na temat projektu zmian dotyczących adopcji ze wskazaniem, stwierdzając, że wstępna wersja zmian ustawy nie bierze pod uwagę w odpowiednim stopniu zasady dobra dziecka, a także zbyt bardzo ogranicza krąg osób, które mogą dokonać przysposobienia za pomocą wskazania. Krajowa Rada Sądownictwa w swoim uzasadnieniu stwierdziła, iż: „ZZałożenia projektu pomijają, że w kręgu krewnych bądź powinowatych często występują te same dysfunkcje społeczne, które

13 Pismo Ministra Pracy i Polityki Społecznej z 23 lipca 2013 r. dotyczące projektu ustawy o zmianie ustawy o zmianie ustawy Kodeks rodzinny i opiekuńczy oraz ustawy Kodeks postępowania cywilnego, s. 1-3,https://brpd.gov.pl/sites/default/files/rpd_stare/ wystapienia/wyst_2013_04_19_mpips.pdf, dostęp 5 grudnia 2017 r.

14 Ibidem. 
dotyczą rodziców dziecka i nie przemawiają za przysposobieniem dziecka przez takie osoby” ${ }^{15}$. W swojej opinii dodała, że: „Poważne zastrzeżenia budzi również koncepcja składania wniosku o przysposobienie za pośrednictwem ośrodka adopcyjnego. [...]. Nietrafne jest stwierdzenie zawarte w uzasadnieniu projektu, że pośrednictwo ośrodka adopcyjnego skróci czas trwania postępowania adopcyjnego, ponieważ ograniczy potrzebę uzupełnienia wniosków z powodu braków formalnych na etapie postępowania sądowego. [...]. Konieczność składania wniosku o przysposobienie za pośrednictwem ośrodka adopcyjnego może być uznana za utrudnienie w realizacji prawa do adopcji, dla którego przewidziano drogę sądową, tym bardziej, że ustawodawca nie wskazał terminu, w którym ośrodek adopcyjny miałby przekazywać sądowi wniosek wraz z dokumentami, oraz terminu, w którym sporządzana byłaby opinia o tym wniosku" 16 .

Następnie, 5 czerwca 2014 r. projekt ten został zarejestrowany w Sejmie, pod numerem druku sejmowego 2361 i skierowano go do Komisji Nadzwyczajnej do spraw zmian w kodyfikacjach.

Dwie ostatnie opinie o projekcie zmian kodeksu rodzinnego i opiekuńczego w omawianym zakresie zostały sporządzone przez Biuro Analiz Sejmowych w lipcu $2014 \mathrm{r}$.

W swojej opinii z 9 lipca 2014 r. ekspert do spraw legislacji Biura Analiz Sejmowych dr Jolanta Waszczuk-Napiórkowska wskazała, że projekt wymaga dalszych prac, jednocześnie wyrażając aprobatę co do zmiany przepisów, dotyczącej ograniczenia kręgu przyszłych rodziców przysposabiających do członków rodziny małoletniego dziecka, ponieważ przepis ten ograniczy handel ludźmi. Dlatego też, jeśli przysposobienie służyć ma wykorzystaniu małoletniego dziecka na przykład do pozyskania narządów, wtedy owszem, należy uznać, że jest to handel ludźmi, natomiast jeżeli służy po prostu adopcji, włączeniu do rodziny przysposabiającej, a także wychowywaniu takiego dziecka, to w takiej

15 Opinia Krajowej Rady Sądownictwa z 8 maja 2015 r. w przedmiocie komisyjnego projektu ustawy Kodeks rodzinny i opiekuńczy oraz Kodeks postępowania cywilnego, s. 1-2, http://www.krs.pl/admin/files/opinie-i-stanowiska/140508\%20020\%2048.pdf, dostęp 5 grudnia $2017 \mathrm{r}$.

16 Ibidem, s. 3. 
sytuacji nie można rozważać o handlu ludźmi. Biuro oczywiście uzasadniło w sposób wyczerpujący swoją opinię, dodając, że Sąd Apelacyjny we Wrocławiu w wyroku z 11 grudnia 2013 r. (II AKa 393/13) uniewinnił rodziców naturalnych i przysposabiających za przekazanie małoletniego dziecka do adopcji za uprzednią zapłatą. Podobnie wypowiedział się Sąd Apelacyjny w Gdańsku w postanowieniu z 13 sierpnia 2013 r. w sprawie II AKz 475/13 ${ }^{17}$, co zostanie szerzej wyjaśnione w dalszej części niniejszego artykułu.

W kolejnej opinii z 4 lipca 2014 r., sporządzonej przez Panią Jolantę Szymańczak, specjalistkę do spraw społecznych Biura Analiz Sejmowych, wskazano, że adopcja ze wskazaniem jest legalną instytucją prawną i nadużyciem są upowszechniane przez media spostrzeżenia, iż każdy tego rodzaju wyrok sądu stanowi umowę handlową, występującą pomiędzy rodzicami biologicznymi małoletniego dziecka i adoptującymi. Biuro w swojej ocenie uznało również, że stwierdzenie głoszące, iż nielegalna adopcja rozwija się poprzez instytucję przysposobienia ze wskazaniem, godzi w niezawisłość sędziowską, stwarza negatywną opinię o funkcjonowaniu sądów, a także podważa kompetencje sędziów rodzinnych ${ }^{18}$.

Opinie Biura Analiz Sejmowych różnią się nieco od siebie ze względu na to, że pierwsza $z$ nich została sporządzona przez eksperta do spraw legislacji ${ }^{19}$, natomiast drugi pogląd został zaprezentowany przez specjalistę do spraw społecznych ${ }^{20}$. Przykładowo, druga opinia Biura wskazała, że ograniczenie przysposobienia do kręgu rodzinnego wydaje się środkiem mało skutecznym, ponieważ nie zlikwiduje nadużyć w procesie adopcyjnym, a dodatkowo pośrednictwo ośrodka adopcyjnego

17 J. WAszczUK-NAPIÓRKowsKA, Opinia prawna z 9.07.2014 r. dotycząca projektu ustawy o zmianie kodeksu rodzinnego i opiekuńczego oraz kodeksu postępowania cywilnego, druk sejmowy nr 2361, s. 1-9, http://www.sejm.gov.pl/sejm7.nsf/PrzebiegProc. $\mathrm{xsp}$ ?nr=2361, dostęp 5 grudnia $2017 \mathrm{r}$.

18 J. SzymańCZAK, Opinia do komisyjnego projektu ustawy z 4.07.2014 r. o zmianie kodeksu rodzinnego i opiekuńczego oraz kodeksu postępowania cywilnego, druk sejmowy $n r$ 2361, s. 1-8, http://www.sejm.gov.pl/sejm7.nsf/PrzebiegProc.xsp?nr=2361, dostęp 5 grudnia $2017 \mathrm{r}$.

19 J. WASZCZUK-NAPIÓRKOWSKA, op. cit., s. 1-9.

20 J. SzymańCZAK, op. cit., s. 1-8. 
w składaniu wniosku do sądu rodzinnego może znacznie ograniczyć prawo do sądu ${ }^{21}$.

Dnia 5 sierpnia 2015 r. prezydent Bronisław Komorowski podpisał zmianę ustawy z 24 lipca 2015 r. o zmianie ustawy - Kodeks rodzinny i opiekuńczy, mimo negatywnych w tym zakresie opinii nie tylko ze strony wyżej omówionej między innymi Krajowej Rady Sądownictwa, lecz także pomimo krytycznej oceny Prokuratora Generalnego oraz Sądu Najwyższego.

Nowelizacja wprowadziła do kodeksu rodzinnego i opiekuńczego art. $119^{1}$ a o następującej treści: „Rodzice mogą przed sądem opiekuńczym wskazać osobę przysposabiającego, którą może być wyłącznie krewny rodziców dziecka za zgodą tej osoby złożoną przed tym sądem. Osobą wskazaną może być również małżonek jednego z rodziców”.

Podsumowując, w kodeksie rodzinnym i opiekuńczym dodano normę stwierdzającą, że rodzice mogą przed sądem opiekuńczym wyznaczyć przysposabiającego, którym może być tylko i wyłącznie krewny rodziców dziecka. Osobą wskazaną może być również współmałżonek drugiego z rodziców. Należy podkreślić, że w powyższych sytuacjach wyznaczony adoptujący także musi wyrazić zgodę na bycie przysposabiającym, a aprobata winna być złożona przed tym samym sądem opiekuńczym²2.

\section{PRocedura ADOPCYJNA I OPINIA O ADOPCJI ZE WSKAZANIEM PO NOWELIZACJI}

Zgodnie z art. $119^{2}$ k.r.o. rodzice, którzy nie chcą wychowywać swojego dziecka, najwcześniej sześć tygodni po jego urodzeniu mogą wyrazić zgodę na przysposobienie, a w związku z art. 11911a k.r.o. po upływie tego terminu mogą wskazać spokrewnionych lub spowinowaconych jako osoby przysposabiające ich biologiczne dziecko ${ }^{23}$.

\footnotetext{
21 J. Waszczuk-NAPiórkowsKa, op. cit., s. 1-9.

22 K. Tryniszewska, op. cit., s. 96-97.

23 Ibidem.
} 
Krewni, będący kandydatami na przysposabiających, zgodnie z art. 172 ust. 2 pkt 1 ustawy z 9 czerwca 2011 r. o wpieraniu rodziny i systemie pieczy zastępczej nie mają obowiązku ukończenia szkolenia adopcyjnego.

Przysposobienie przez rodzinę ma miejsce zazwyczaj wtedy, kiedy dziecko zostanie osierocone w wyniku śmierci obojga rodziców. Wtedy jednak zgodę na adopcję wyraża opiekun dziecka, a omawiana zmiana Z września $2015 \mathrm{r}$. nie przewiduje tego rodzaju sytuacji ${ }^{24}$.

Zgodnie z nową regulacją kodeksową rodzice biologiczni, którym nie można postawić żadnego zarzutu wychowawczego (czyli przyczyny ich decyzji o oddaniu dziecka do adopcji nie są przez nich zawinione), są zmuszeni wyrazić zgodę blankietową na adopcję, jeżeli krewni dziecka nie są godni lub też chętni podjęcia się trudu wychowawczego. Dziecko $\mathrm{w}$ tej sytuacji zostaje umieszczone $\mathrm{w}$ rodzinie zastępczej do momentu ewentualnego przysposobienia, mimo że pośród niespokrewnionych czy niespowinowaconych bliskich dziecka jest osoba, która mogłaby i wyrażałaby chęć podjęcia takiego zobowiązania. Dlatego też uchwalona nowelizacja kodeksu rodzinnego i opiekuńczego poprzez ograniczenie kręgu osób mogących zostać wskazanymi przez rodziców biologicznych jako przyszli adoptujący może w pewnych sytuacjach wręcz naruszać dobro dziecka ${ }^{25}$.

Wprowadzona zmiana uderza zwłaszcza w uczciwych ludzi, zarówno tych, którzy pragną powierzyć opiekę zaufanym osobom (innym niż spokrewnieni) nad swoim biologicznym dzieckiem, jak i w adoptujących, którzy korzystając ze swoich praw osobistych, pragną dla dziecka dobra i kochającej je rodziny. Należy zwrócić szczególną uwagę na to, że trudno zobligować rodziców naturalnych do wskazania przysposabiających dla swojego małoletniego dziecka z kręgu rodzinnego, a nowo wprowadzona regulacja narzuca tylko taką możliwość. Wydaje się, że ustawodawca w omawianych zmianach przepisów nie zwrócił uwagi na dość istotny

24 Stanowisko Rządu z 23.02.2015 r. wobec komisyjnego projektu ustawy o zmianie ustawy - Kodeks Rodzinny i Opiekuńczy oraz ustawy - Kodeks Postępowania Cywilnego, druk sejmowy nr 2361, s. 1-3, http://www.sejm.gov.pl/sejm7.nsf/PrzebiegProc. $\mathrm{xsp}$ ?nr=2361, dostęp 5 grudnia $2017 \mathrm{r}$.

25 Ibidem, s. 3. 
problem, a mianowicie na to, że środowiska rodzinne (spokrewnione i spowinowacone) $\mathrm{z}$ rodzicami naturalnymi mogą być podobne do siebie, przedstawiając dysfunkcje społeczne, z których rodzice biologiczni pragną wyrwać własne dziecko, szukając dla małoletniego rodziny, która przedstawi lepsze warunki, niż mogą zagwarantować oni sami.

5. INTERPRETACJA KOMISJI I PODKOMISJI SEJMOWYCH W SPRAWIE ADOPCJI ZE WSKAZANIEM

Wprowadzona zmiana dotycząca adopcji ze wskazaniem poprzez jej formalne uregulowanie $\mathrm{w}$ art. $11^{1}$ a k.r.o. przestaje być jednoznaczna po dokładnym przeanalizowaniu nagrań z posiedzeń podkomisji i komisji sejmowych, które rozpatrywały nowo zaprojektowane regulacje. Dlatego też poniżej zostanie przedstawiona nowa wykładnia adopcji ze wskazaniem ze szczególnym uwzględnieniem interpretacji podkomisji i komisji sejmowych. Źródłem tych informacji są nagrania z posiedzeńn ${ }^{26}$.

Podczas prac komisji przedstawiciele Ministerstwa Sprawiedliwości zgłaszali swoje wątpliwości, odnosząc się nie tylko do celowości nowych regulacji, lecz także do jej skutków, ze względu na brak zmiany art. 119 k.r.o. ${ }^{27}$ Wyjaśniając, zgodnie tym przepisem do adopcji jest potrzebna zgoda rodziców adoptowanego, , chyba że zostali oni pozbawieni władzy rodzicielskiej lub są nieznani albo porozumienie się z nimi napotyka trudne do przezwyciężenia przeszkody". Ustawodawcy tej normy liczyli na to, że wprowadzenie art. $11^{1}$ a do kodeksu rodzinnego i opiekuńczego spowoduje, iż tzw. podziemie adopcyjne zostanie zmniejszone dzięki wprowadzeniu ograniczenia kręgu osób mogących przysposobić dziecko do krewnych i małżonka rodzica. W trakcie trwania posiedzeń w Sejmie uczestnicy podkreślili, że brak zmiany art. 119 k.r.o. doprowadzi mimo wszystko do tego, że w dalszym ciągu omawiana adopcja ze

26 Komisyjny projekt ustawy o zmianie Kodeksu Rodzinnego i Opiekuńczego oraz Kodeksu Postępowania Cywilnego z 24 czerwca 2015 r., druk sejmowy 2361, Nagranie z posiedzeń komisji i podkomisji sejmowych, http://www.sejm.gov.pl/SQL2. nsf/poskomprocall?OpenAgent\&7\&2361, dostęp 5 grudnia 2017 r.

27 Ibidem. 
wskazaniem będzie dopuszczalna na rzecz osób spoza kręgu krewnych i małżonka rodzica. Należy podkreślić, że art. 119 k.r.o. stwierdza, iż do przysposobienia niezbędna jest zgoda rodziców posiadających władzę rodzicielską, a wprowadzony do kodeksu rodzinnego i opiekuńczego art. $119^{1}$ a posługuje się innym terminem niż „zgoda”, a mianowicie „wskazaniem” kandydatów do adopcji małoletniego dziecka. Konieczne wydaje się podkreślenie, że te dwa pojęcia: „zgoda” i „wskazanie” nie są ze sobą tożsame. Podsumowując, zgodnie z art. 119 k.r.o. w ogóle nie dochodzi do wskazania kandydatów na rodziców przysposabiających, ponieważ rodzice biologiczni małoletniego dziecka, działając zgodnie z tym przepisem, wyrażają zgodę, by ich własne dziecko zostało przysposobione przez osoby, które złożyły odpowiedni wniosek, a z kolei nowo dodana regulacja prawna wprost określa, że rodzic biologiczny wskazuje jako rodzica przysposabiającego swojego krewnego albo małżonka. Dlatego też próba zlikwidowania podziemia adopcyjnego nie sprawdzi się w praktyce, ponieważ nadal pojawiają się ogłoszenia na temat tego typu adopcji na forach internetowych. Podziemie adopcyjne wykorzystało niezmieniony art. 119 k.r.o., traktując to jako dodatkową alternatywę, dzięki której zgodnie z prawem można przysposobić dziecko, ale tym razem za zgodą rodziców naturalnych, a nie w drodze wskazania przez biologicznych rodziców ${ }^{28}$.

Zatem zgodnie z art. 119 k.r.o. zgoda wyrażona przez rodziców biologicznych oznacza, że przysposabiającym dziecko są osoby obce. Z kolei działając w zakresie art. 119¹a k.r.o., rodzice naturalni wskazują kogoś w obrębie własnej rodziny. W rezultacie nowe przepisy nie wniosły nic nowego ani w żadnym zakresie nie ograniczyły problemu, z jakim wystąpił w początkowej fazie projektu Rzecznik Praw Dziecka ${ }^{29}$. 


\section{AdopCJA ZE WSKAZANIEM A HANDEL DZIEĆMI}

Pisząc w niniejszym artykule o problemach związanych $\mathrm{z}$ adopcją ze wskazaniem, nie można pominąć omówienia problemu, który przez kilka lat był rozpowszechniany w mediach społecznego przekazu, a jednocześnie zajmowały się nim organizacje pozarządowe działające na rzecz dzieci. Chodzi przede wszystkim o to, że za pomocą adopcji ze wskazaniem w poprzednim stanie prawnym dzieci były obiektem transakcji handlowych; innymi słowy, poprzez podziemie adopcyjne, działające w szczególności przez fora internetowe, poszukiwano dzieci (niemowląt) do adopcji, a także informowano o chęci przekazania już narodzonych dzieci do przysposobienia za odpowiednią sumę pieniężną ${ }^{30}$.

Rzecznik Praw Dziecka był zwolennikiem wprowadzonej nowelizacji, ponieważ w swojej opinii dotyczącej jeszcze prac nad jej projektem wyraźnie stwierdził, że przysposobienie ze wskazaniem winno służyć adopcji wewnątrzrodzinnej, innymi słowy, opieka nad dzieckiem powinna należeć do krewnych i powinowatych. Jednocześnie oznacza to, że ci, którzy nie są w żadnym stopniu spokrewnieni czy spowinowaceni z dzieckiem, zostają wykluczeni z grona osób, które mogą być wskazane jako przysposabiający. Zgodnie ze zdaniem Rzecznika Praw Dziecka takie uwarunkowanie pozwala rodzicom biologicznym na możliwość decydowania o przyszłości ich własnego dziecka przy jednoczesnym wykluczeniu, że adopcja ze wskazaniem ma tylko i wyłącznie pobudki dążące ku temu, aby osiągnąć korzyści majątkowe przez rodziców naturalnych małoletniego dziecka ${ }^{31}$.

\subsection{KomerCyjnA ADOPCJA}

Pojęcie adopcji komercyjnej nie znalazło się oficjalnie w terminologii prawniczej, jednak w potocznym języku używane jest dość często. Termin ten opisuje w szczególności sytuację, w której doszło do oddania,

30 R. ŁukAsiewicz, Prawna regulacja przysposobienia ze wskazaniem a problem handlu dziećmi, «Monitor Prawniczy» 3/2016, s. 122-125.

31 Pismo Rzecznika Praw Dziecka z 19 kwietnia 2013 r., sporządzone w celu uregulowania tzw. adopcji ze wskazaniem, s. 1-2, http://brpd.2012korczak.pl/sites/default/ files/rpd_stare/wystapienia/wyst_2013_04_19.pdf, dostęp 5 grudnia 2017 r. 
a następnie do przyjęcia małoletniego dziecka w celu przysposobienia w zamian za przekazanie i przyjęcie korzyści majątkowej. Należy tutaj dodać, że korzyść taką pobierają rodzice naturalni dziecka od kandydatów na adoptujących. Za naganne postępowanie uważa się wszelkiego rodzaju zachowania i motywy, które świadczą o chęci zapłacenia przez adoptujących na rzecz rodziny biologicznej, za udzielenie pomocy w uzyskaniu praw rodzicielskich względem dziecka. Należy wskazać, że w niektórych sytuacjach rodzice przysposabiający faktycznie ponosili zasadne wydatki związane z ciążą, porodem czy połogiem, których nie byli w stanie ponieść naturalni rodzice, a w związku z tym pewne opłaty dokonywane przez przyszłych przysposabiających są w pełni uzasadnione i nie mają na celu tylko i wyłącznie potrzeby kupienia dziecka, lecz jego dobro ${ }^{32}$.

Przepisy kodeksu rodzinnego i opiekuńczego w ogóle nie odnoszą się do powyżej omawianej kwestii - nie zostało to unormowane ani tym bardziej usankcjonowane. Należy również zauważyć, że wszystkie osoby, które uczestniczą w procedurze adopcyjnej, powinny kierować się fundamentalną zasadą, jaką jest najlepszy interes małoletniego dziecka, a nie chęcią otrzymania korzyści finansowych ${ }^{33}$.

\subsection{Komercyjna adopcja a handel dziećmi}

Przypadki opisane powyżej mieszczą się w granicach prawa i nie wykluczają drogi postępowania sądowego, dlatego nie są kwalifikowane jako przestępstwo dotyczące handlu ludźmi. Warto wskazać w tym miejscu na przedmiot postępowań sądowych z 2013 r., jakim były kwestie dotyczące odpłatnego, pozasądowego przekazania małoletnich dzieci.

Sąd Apelacyjny we Wrocławiu w wyroku z 11 grudnia 2013 r. (II AKa 393/13) uniewinnił rodziców biologicznych oraz adoptujących za przekazanie dziecka do przysposobienia za uprzednią zapłatą. Podobnie wypowiedział się Sąd Apelacyjny w Gdańsku w postanowieniu z 13 sierpnia 2013 r. w sprawie II AKz 475/13.

32 M. Pomarańska-Bielecka, Analiza przepisów dotyczacych zapobiegania i przeciwdziałania zjawisku handlu dziećmi, Warszawa 2010, s. 22-25.

33 Ibidem. 
W pierwszym przypadku, rozpoznawanym przez wrocławski Sąd Okręgowy, oskarżonymi byli biologiczni rodzice, którzy jeszcze przed narodzinami ich własnego dziecka nawiązali za pośrednictwem internetu kontakt z kobietą, uzgadniając z nią, że po urodzeniu przekażą jej dziecko. W zamian za to kobieta zapłaciła naturalnym rodzicom odpowiednią sumę pieniędzy oraz pokryła koszty związane z ciążą i porodem. We wskazanym przypadku kobieta przekazała swój dokument tożsamości ciężarnej wraz z ubezpieczeniem, a ciężarna wykorzystała je jako własne podczas pobytu w szpitalu ${ }^{34}$.

Druga sprawa, rozstrzygana przez Sąd Apelacyjny w Gdańsku, dotyczyła bardzo podobnej sytuacji. W tym przypadku romska para, która nie mogła mieć dzieci, nakłoniła ciężarną kobietę do oddania własnego dziecka w zamian za otrzymanie korzyści materialnych. Strony postępowania dopuściły się także poświadczenia nieprawdy w dokumentacji urzędowej, ponieważ w celu zarejestrowania noworodka poręczyli, że dziecko jest biologicznym dzieckiem romskiej pary zamieszkującej w Polsce ${ }^{35}$.

Sąd pierwszej instancji w drugiej opisywanej sytuacji uznał za niewinnych romską parę, a Sąd Apelacyjny w tej sprawie, po ponownym rozpatrzeniu okoliczności, podtrzymał wyrok pierwszej instancji, uwalniając ich od zarzutu handlu ludźmi ${ }^{36}$. Wyrok sądowy w pierwszej $\mathrm{z}$ omawianych spraw wyglądał podobnie, ponieważ sąd uniewinnił zarówno rodziców naturalnych, jak i kobietę, która przyjęła od nich noworodka ${ }^{37}$.

W obu rozwiązaniach przyjętych przez sądy można zauważyć, że wymiar sprawiedliwości uznał, iż oskarżeni nie dopuścili się przemocy w stosunku do dziecka, a ich fundamentalnym celem nie była chęć wykorzystania dziecka, ale zapewnienie mu odpowiednich warunków życia ${ }^{38}$.

\footnotetext{
34 Orzeczenie SA z 11 grudnia 2013 r., II AKa 393/2013, «Lex».

35 Orzeczenie SA z 13 sierpnia 2013 r., II AKz 475/13, «Lex».

36 Ibidem.

37 Orzeczenie SA z 11 grudnia 2013 r., II AKa 393/13, «Lex».

38 Orzeczenie SA z 11 grudnia 2013 r., II AKa 393/13, «Lex»; orzeczenie SA z 13 sierp-
} nia 2013 r., II AKz 475/13, «Lex». 


\section{Podsumowanie}

Podsumowując, przed wejściem w życie nowelizacji kodeksu rodzinnego i opiekuńczego adopcja ze wskazaniem rozumiana była jako możliwość przysługująca rodzicom biologicznym, którzy mieli prawo do wyznaczenia osoby adoptującej; z kolei zgodnie z nową normą zawartą w art. $119^{1}$ a k.r.o. wskazanie to zostało ograniczone i przysposabiającym może być tylko „[...] krewny rodziców dziecka za zgodą tej osoby złożoną przed tym sądem. Osobą wskazaną może być również małżonek jednego z rodziców”.

Dlatego też nowo wprowadzona regulacja do kodeksu rodzinnego i opiekuńczego jest nieobiektywna, ponieważ uderza nie tylko w uczciwych ludzi, którzy pragną powierzyć opiekę nad własnym dzieckiem zaufanym osobom, jak i w samych przysposabiających, którzy generalnie pragną dla dziecka dobra i kochającej rodziny.

Ustawodawca w zmodyfikowanych normach nie spostrzegł dość istotnego problemu; takiego, że spokrewnione i spowinowacone środowiska rodzinne dość często są podobne do siebie, prezentując liczne dysfunkcje społeczne, z których rodzice naturalni wręcz pragną wyrwać własne dziecko, poprzez szukanie dla małoletniego rodziny przedstawiającej lepsze warunki, niż mogą zagwarantować oni sami. Prawodawca nie zwrócił natomiast uwagi na istotę samego problemu, a mianowicie na to, że tradycyjna procedura adopcyjna jest zbyt długotrwała. Ze względu na przedłużające się rutynowe procedury adopcyjne, zarówno rodzice adopcyjni, jak i biologiczni decydują się na wykorzystanie nadal niezlikwidowanych luk prawnych, aby w ten sposób uniknąć przedłużających się formalności i jednocześnie dbać o dobro samego dziecka. Przykładowo, pomimo zmian w przepisach, rodzice biologiczni i osoby, które pragną przysposobić dziecko na skutek tzw. wskazania, i tak tego dokonają, między innymi wykorzystując okoliczności wskazane w wyroku z 11 grudnia 2013 r. (II AKa 393/13). 
ADOPCJA ZE WSKAZANIEM ZGODNIE Z NOWYM UREGULOWANIEM PRAWNYM

\section{Streszczenie}

Celem niniejszego artykułu jest wyjaśnienie instytucji adopcji ze wskazaniem, jej formy i treści, obejmującej osoby uprzywilejowane do przysposobienia, do których zalicza się krewnych rodziców dziecka oraz małżonka jednego z rodziców. Ukazane zostaną także stanowiska między innymi Rzecznika Praw Dziecka, Ministra Pracy i Polityki Społecznej, Krajowej Rady Sądownictwa, Biura Analiz Sejmowych w sprawach związanych $\mathrm{z}$ adopcją ze wskazaniem. Zwrócona zostanie również szczególna uwaga na handel dziećmi, z którym jest związana problematyka adopcji ze wskazaniem. Przed wejściem w życie nowelizacji kodeksu adopcja ze wskazaniem była możliwa nie tylko w stosunku do konkretnego kręgu osób, lecz także dla wszystkich tych, którzy zostali wskazani przez biologicznych rodziców dziecka. Jak wynika z nowych przepisów, w przypadku adopcji ze wskazaniem krewni rodziców będą mieli ułatwioną procedurę adopcyjną, natomiast pozostali zainteresowani będą mogli adoptować małoletnie dziecko tylko za pośrednictwem ośrodka adopcyjnego.

\section{Designated Adoption under the new Polish Legislation}

\section{Summary}

The purpose of this paper is to explain the institution of designated adoption in Poland, with its specific procedure of preference for designated adoptive parents (e.g. natural parents' relatives or the spouse of one of the parents). It summarises opinions on this issue presented by the main government institutions which have a significant impact on social policy in Poland, namely, the Children's Ombudsman, the Ministry of Labour and Social Policy, the National Council of the Judiciary of Poland and the Bureau of Research attached to the Chancellery of Sejm. 
The paper also addresses the problem of child trafficking, which is associated with designated adoption. Prior to the entry into force of the recent amendment to the Family Code, designated adoption was admissible not only for a close family member of the natural parents, but in fact any person indicated by a biological parent had a right to adopt the child, which left a loophole for child trafficking. Under the new provisions the legal procedures for designated adoption by relatives of the birth parents will be facilitated, while other prospective adoptive parents will be able to apply only through the mediation services of an adoption agency.

Słowa kluczowe: Adopcja, przysposobienie; adopcja ze wskazaniem; przysposobienie ze wskazaniem; przysposabiający; przysposobiony; adoptujący; adoptowany; rodzice biologiczni; handel dziećmi.

Keywords: Adoption; designated adoption; adoptive parent; adopted child; biological parents; child trafficking.

\section{Literatura}

Bagan-Kurluta K., Przysposobienie międzynarodowe dzieci, Białystok 2009. НАак H., Kodeks rodzinny i opiekuńczy. Przysposobienie. Komentarz, Toruń 1996.

Holewińska-Łapińska E., Przysposobienie rozwiązywalne w orzecznictwie sądów powszechnych, Instytut Wymiaru Sprawiedliwości, Warszawa 2014, s. 1-3, https://www.iws.org.pl/pliki/files/_Przysposobienie \%20rozwi\%C4\%85zywalne \%20w\%20orzecznictwie\%20s\%C4\%85d\%C3\% B3w\%20powszechnych\%20wersja\%20bez\%20sygnatur.pdf, dostęp 5 grudnia $2017 \mathrm{r}$.

IgnATOWICZ J., Ochrona praw rodzinnych, [w:] Kodeks rodzinny i opiekuńczy $z$ komentarzem, red. J. Pietrzykowski, Warszawa 1990.

Komisyjny projekt ustawy o zmianie Kodeksu Rodzinnego i Opiekuńczego oraz Kodeksu Postępowania Cywilnego z 24 czerwca 2015 r., druk sejmowy 2361, Nagranie z posiedzeń komisji i podkomisji sejmowych, http://www.sejm.gov. pl/SQL2.nsf/poskomprocall?OpenAgent\&7\&2361, dostęp 5 grudnia 2017 r. ŁUKASIEWICZ R., Prawna regulacja przysposobienia ze wskazaniem a problem handlu dziećmi, «Monitor Prawniczy» 3/2016. 
Opinia Krajowej Rady Sądownictwa z 8 maja 2015 r. w przedmiocie komisyjnego projektu ustawy Kodeks rodzinny i opiekuńczy oraz Kodeks postępowania cywilnego, s. 1-2, http://www.krs.pl/admin/files/opinie-i-stanowiska/140508\%20020\%2048.pdf, dostęp 5 grudnia 2017 r.

Pismo Komisji Polityki Społecznej i Rodziny z 14 marca 2014 r., druk sejmowy nr 2361, Projekt ustawy o zmianie Kodeksu rodzinnego i opiekuńczego oraz Kodeksu postępowania cywilnego. Uzasadnienia, s. 4-5, http://www.sejm. gov.pl/sejm7.nsf/PrzebiegProc.xsp?nr=2361, dostęp 5 grudnia 2017 r.

Pismo Ministra Pracy i Polityki Społecznej z 23 lipca 2013 r. dotyczące projektu ustawy o zmianie ustawy o zmianie ustawy Kodeks rodzinny i opiekuńczy oraz ustawy Kodeks postępowania cywilnego, s. 1-3, https://brpd.gov.pl/sites/default/files/rpd_stare/wystapienia/ wyst_2013_04_19_mpips.pdf, dostęp 5 grudnia 2017 r.

Pismo Rzecznika Praw Dziecka z 19 kwietnia 2013 r., sporządzone w celu uregulowania tzw. adopcji ze wskazaniem, s. 1-2, http://brpd.2012korczak. pl/sites/default/files/rpd_stare/wystapienia/wyst_2013_04_19.pdf, dostęp 5 grudnia $2017 \mathrm{r}$.

PŁonka E., Przysposobienie całkowite w prawie polskim, Wrocław 1986.

Pomarańska-Bielecka M., Analiza przepisów dotyczących zapobiegania i przeciwdziałania zjawisku handlu dziećmi, Warszawa 2010.

Tryniszewska K., Prawo rodzinne. Komentarz. Odpowiedzi na pytania. Wzory dokumentów. Akty prawne, Warszawa 2016.

Szymańczak J., Opinia do komisyjnego projektu ustawy z 4.07.2014 r. o zmianie kodeksu rodzinnego i opiekuńczego oraz kodeksu postępowania cywilnego, druk sejmowy nr 2361, s. 1-8, http://www.sejm.gov.pl/sejm7.nsf/PrzebiegProc. $\mathrm{xsp}$ ?nr=2361, dostęp 5 grudnia $2017 \mathrm{r}$.

Stanowisko Rządu z 23.02.2015 r. wobec komisyjnego projektu ustawy o zmianie ustawy - Kodeks Rodzinny i Opiekuńczy oraz ustawy - Kodeks Postępowania Cywilnego, druk sejmowy nr 2361, s. 1-3, http://www.sejm.gov.pl/sejm7.nsf/ PrzebiegProc.xsp?nr=2361, dostęp 5 grudnia 2017 r.

Waszczuk-NAPIóRKowska J., Opinia prawna z 9 lipca 2014 r. dotyczaca projektu ustawy o zmianie kodeksu rodzinnego i opiekuńczego oraz kodeksu postępowania cywilnego, druk sejmowy nr 2361, s. 1-9, http://www.sejm.gov. pl/sejm7.nsf/PrzebiegProc.xsp?nr=2361, dostęp 5 grudnia 2017 r. 